\title{
Pengaruh Fraud Diamond Dan Gonetheory Terhadap Academic Fraud
}

\author{
Silfani Neva ${ }^{1}$, Firdaus Amyar ${ }^{2}$ \\ DOl: https://doi.org/10.36339/jaspt.v5i1.408
}

\begin{abstract}
This research examines the factors of pressure, opportunity, rationalization, ability, greed, need, and disclosure of academic fraud behavior in accounting students at Institute of Business and Informatics Kesatuan Bogor. This type of research is a quantitative study, using a questionnaire as a research instrument measured by a Likert scale. This study used a sample of 306 students who had already participated in filling out the questionnaire that the researcher had distributed in the form of a Google Form. The data analysis technique used is multiple linear regression analysis using the IBM SPSS version 25 software. The results of this study indicate that the opportunity and need factors affect the academic fraud of accounting students at the Bogor Institute of Business and Informatics, while the factors of pressure, rationalization, ability, greed, and disclosure have no effect on academic fraud committed by accounting students at the Institute of Business and Informatics Kesatuan.
\end{abstract}

Keywords: Pressure, opportunity, rationalization, ability, greed, need, disclosure, academic fraud, diamond fraud, GONE Theory.

\section{Abstrak}

Penelitian ini menguji factor dari tekanan, kesempatan, rasionalisasi, kemampuan, keserakahan, kebutuhan, dan pengungkapan terhadap perilaku kecurangan akademik pada mahasiswa Akuntansi di Institut Bisnis dan Informatika Kesatuan Bogor. Jenis penelitian ini merupakan penelitian kuantitatif, dengan menggunakan kuesioner sebagai instrumen penelitian yang diukur dengan skala likert. Penelitian ini menggunakan sampel 306 mahasiswa yang sudah berpartisipsi dalam pengisian kuesioner yang telah dibagikan peneliti dalam bentuk Google Form. Teknik analisis data yang digunakan adalah analisis regresi linier berganda dengan menggunakan software IBM SPSS versi 25. Hasil penelitian ini yaitu bahwa factor kesempatan dan kebutuhan berpengaruh pada tindak kecurangan akademik mahasiswa Akuntansi di Institut Bisnis dan Informatika Kesatuan Bogor sedangkan factor tekanan, rasionalisasi, kemampuan, keserakahan, dan pengungkapan tidak berpengaruh pada tindak kecurangan akademik yang dilakukan mahasiswa Akuntansi di Institut Bisnis dan Informatika Kesatuan Bogor.

Kata Kunci: Tekanan, Kesempatan, Rasionalisasi, Kemampuan, Keserakahan, kebutuhan, pengungkapan, kecurangan akademik, fraud diamond, GONE Theory.

\section{PENDAHULUAN}

Pendidikan merupakan suatu hal pokok bagi peradaban manusia saat ini. Salah satu fungsi pendidikan adalah untuk membentuk watak dan kepribadian sejak dini.Pendidikan juga menjadi suatu tolak ukur kemajuan suatu bangsa. Pendidikan di perguruan tinggi

Program Studi Akuntansi, Institut Bisnis dan Informatika Kesatuan

2. Program Studi Akuntansi, Institut Bisnis dan Informatika Kesatuan, Jalan Ranggagading No 1 Bogor West Java, Indonesia

Email of Corresponding Author : Firdaus.kesatuan@gmail.com

Submitted : November 2020

Accepted : Februari 2021

JURNAL ANALISIS SISTEM PENDIDIKAN TINGGI

ISSN 2580 - 5339

eISSN 2620 - 5718

Volume 5

Nomor 1

JULI 2021

Hal $29-38$

DOSEN INDONESIA SEMESTA 
diharapkan dapat menghasilkan manusia yang tidak hanya berbekal ilmu pengetahuan saja, namun memiliki nilai kejujuran yang nantinya dapat diimplementasikan dalam dunia kerja atau usaha.

Dalam pendidikan tinggi, tentunya sering ditemukan kecurangan-kecurangan (fraud) yang dilakukan oleh mahasiwa demi menghasilkan nilai hasil output yang memuaskan bagi mereka. Hal ini memperbesar kemungkinan untuk melakukan kecurangan juga pada dunia kerja atau usaha. Oleh karena itu, perguruan tinggi mempunyai peran penting untuk dapat membimbing mahasiswa menghindari melakukan kecurangan tersebut sejak dini untuk meminimalisir peluang melakukan kecurangan di kemudian hari.

Berkaitan dengan kecurangan yang terjadi pada dunia kerja termasuk dalam bidang pendidikan, terdapat hasil penelitian yang menunjukkan keterlibatan pendidik atau guru dalam melakukan kecurangan akademik dalam rangka meningkatkan pencapaian nilai peserta didiknya pada suatu sistem ujian (Kane \& Staiger, 2002, dalam Anderman \& Murdock, 2007).

Kecurangan akademik dapat menimbulkan efek yang buruk/negatif bagi mahasiswa, karena nilai yang didapatkan tidak mencerminkan kemampuan dan pemahaman mahasiswa yang sebenarnya. Beberapa contoh Academic fraud menurut oleh Arizona State University Integrity Advocates, kategori tersebut adalah plagiat, pemalsuan data, penggandaan tugas, menyontek pada saat ujian, kerja sama yang salah.

Academic fraud biasanya dilakukan disebabkan beberapa faktor Menurut Hendricks (2004) terdapat beberapa faktor yang mempengaruhi kecurangan akademis yaitu:

1. Faktor individual

Variabel-variabel tersebut adalah usia, jenis kelamin, prestasi akademis, pendidikan orangtua, dan kegiatan ekstrakulikuler.

2. Faktor kepribadian mahasiswa

Berkaitan dengan moralitas, variabel yang berkaitan dengan pencapaian akademis, impulsivitas, afektivitas, dan variabel kepribadian yang lain.

3. Faktor kontekstual

Faktor kontekstual antara lain keanggotaan perkumpulan mahasiswa, perilaku teman sebaya, dan penolakan teman sebaya terhadap perilaku curang.

4. Faktor situasional

Faktor situasional seperti belajar terlalu banyak, kompetisi ukuran kelas, dan lingkungan ujian.

Fraud atau kecurangan terjadi karena beberapa faktor. Donald Cressey (1953) dalam Indriyani (2016) mengungkapkan bahwa setiap terjadinya suatu kecurangan dipengaruhi oleh tiga hal: (1) adanya tekanan/dorongan (pressure/motivation); (2) rasionalisasi/pembenaran (menyangkut etika dan akhlak dari yang bersangkutan); dan (3) adanya peluang/ kesempatan (opportunity) dan pengetahuan (knowledge) untuk melakukan kejahatan. Hasil penelitian Cressey ini kemudian dikenal dengan konsep segitiga fraud (Fraud Triangle).Penelitian fraud selanjutnya dilakukan oleh Wolfe dan Hermanson (2004) yang menambahkan satu elemen fraud lainnya yaitu kemampuan (capability) untuk melengkapi hasil penelitian Cressey sebelumnya, dan mengganti konsep Fraud Triangle menjadi konsep Fraud Diamond Theory.Elemen-elemen dalam

JAS-PT

JURNAL ANALISIS SISTEM PENDIDIKAN TINGG ISSN $2580-5339$ eISSN $2620-5718$ Volume 5

Nomor 1 JULI 2021 Hal 29 - 38
Fraud Diamond Theory ini adalah motivasi/tekanan (motivation/pressure), Kesempatan (opportunity), Rasionalisasi (rasionalization), dan kemampuan (capability).

Nursani (2014), melakukan penelitian nya yang berjudul "Perilaku Kecurangan Akademik Mahasiswa: Dimensi Fraud Diamond" menemukan bahwa terdapat tiga faktor yang mempengaruhi seseorang dalam melakukan kecurangan akademik, yaitu peluang, rasionalisasi, dan kemampuan individu. Kecurangan yang dilakukan sejak dini, dapat terbawa hingga ke dunia kerja atau dunia usaha, salah satu kecurangan pada dunia kerja 
yaitu korupsi. Dalam teori yang dikemukakan oleh Jack Bologne atau sering disebut GONE Theory, ditemukan bahwa faktor faktor yang menyebabkan terjadinya korupsi meliputi greeds (keserakahan), opportunities (kesempatan), needs (kebutuhan), dan exposures (pengungkapan). Faktor-faktor greeds dan needs berkaitan dengan individu pelaku (actor) korupsi, yaitu individu atau kelompok baik dalamorganisasi maupun di luar organisasi yang melakukan korupsi yang merugikan pihak korban. Sedangkan faktor faktor opportunities dan exposures berkaitan dengan korban perbuatan korupsi yaitu organisasi, instansi, masyarakat yang kepentingannya dirugikan.

Penelitian yang dilakukan oleh Zaini (2015) yang berjudul "Analisis Pengaruh Fraud Diamond dan Gone Theory Terhadap Academic Fraud (Studi Kasus Mahasiswa Akuntansi Se-Madura)" menyatakan hasil bahwa tekanan, keserakahan, kebutuhan, dan paparan telah mempengaruhi penipuan akademik. Sementara untuk kesempatan,rasionalisasi, dan kemampuan tidak mempengaruhi kegagalan untuk mendeteksi indikasi penipuan akademik.

Sedangkan penelitian yang dilakukan oleh Reza (2017) yang berjudul "Analisis Dimensi Fraud Diamond dan Gone Theory Terhadap Academic Fraud (Studi Kasus Mahasiswa Akuntansi Fakultas Ekonomi dan Bisnis Universitas Muhammadiyah Surakarta)" memiliki hasil bahwa Hasil penelitian menunjukkan bahwa kesempatan, rasionalisasi dan kemampuan berpengaruh terhadap perilaku kecurangan akademik mahasiswa. Sementara itu, tekanan, keserakahan, kebutuhan dan pengungkapan tidak berpengaruh terhadap perilaku kecurangan akademik mahasiswa.

\section{METODE PENELITIAN}

Penelitian ini menggunakan metode kuantitatif. Menurut Sugiyono (2001), metode kuantitatif merupakan metode positivist karena menganut filsafat positivism aitumetode yang menggunakan metode ilmiah yang memenuhi kaidah-kaidah konkrit atau empiris, objektif, terukur, rasional, dan sistematis. Metode ini juga disebut metode konfitmatif yang digunakan sebagai pembuktian atau konfirmasi dengan menggunakan data penelitian berupa angka-angka dan menggunakan analisa statistic.

Tabel 1 Operasionalisasi Variabel

\begin{tabular}{|c|c|c|c|}
\hline Variabel & Definisi Operasional & Indikator & Skala/Ukuran \\
\hline Tekanan (X1) & $\begin{array}{l}\text { Tekanan (pressure) merupakan } \\
\text { suatu situasi di mana } \\
\text { seseorang merasa perlu untuk } \\
\text { melakukan kecurangan } \\
\text { (Albrecht, 2003). }\end{array}$ & $\begin{array}{l}\text { Indikator tekanan diukur } \\
\text { menggunakan indikator yang } \\
\text { dikembangkan oleh } \\
\text { Pamungkas (2015) dan Zaini } \\
\text { dan Setiawan (2015) yaitu; } \\
\text { 1. keharusan untuk lulus } \\
\text { 2. kompetisi yang tinggi } \\
\text { 3. Tugas yang terlalu banyak } \\
\text { 4. waktu belajar yang tidak } \\
\text { 5. Tukup } \\
\text { Tuntutan dari lingkungan. }\end{array}$ & Skala Likert \\
\hline
\end{tabular}

JAS-PT

JURNAL ANALSIS SISTEM PENDIDIKAN TINGGI ISSN $2580-5339$ eISSN $2620-5718$

Volume 5

Nomor 1

JULI 2021

Hal 29 - 38 


\begin{tabular}{|c|c|c|c|c|}
\hline & $\begin{array}{l}\text { Kesempatan } \\
\text { atan Peluang } \\
(\mathrm{X} 2)\end{array}$ & $\begin{array}{l}\text { Peluang (opportunity) } \\
\text { merupakan suatu situasi ketika } \\
\text { seseorang merasa memiliki } \\
\text { kombinasi situasi dan kondisi } \\
\text { yang memungkinkan dalam } \\
\text { melakukan kecurangan dan } \\
\text { kecurangan tidak terdeteksi } \\
\text { (Albrecht, 2003). }\end{array}$ & $\begin{array}{l}\text { Menurut Wahyudi dan Sopanah } \\
\text { (2010), Albrecht dkk(2012), dan } \\
\text { Prawira(2015) Variabel } \\
\text { kesempatan terdiri atas } \\
\text { beberapa indikator, } \\
\text { diantaranya: } \\
\text { 1. Ketidakkemampuan dari } \\
\text { 2. pihak yang dirugikan } \\
\text { Profesionalisme } \\
\text { 3. Kengawas } \\
\text { 4. Memajuan teknologi. } \\
\text { Menitip absensi kehadiran }\end{array}$ & Skala Likert \\
\hline & $\begin{array}{l}\text { Rasionalisasi } \\
\text { (X3) }\end{array}$ & $\begin{array}{l}\text { Rasionalisasi merupakan } \\
\text { pembenaran diri sendiri atau } \\
\text { alasan yang salah untuk suatu } \\
\text { perilaku yang salah (Albrecht, } \\
\text { 2003). }\end{array}$ & $\begin{array}{l}\text { Variabel rasionalisasi diukur } \\
\text { menggunkana indikator yang } \\
\text { dikembangkan oleh Albrecht } \\
\text { dkk (2012), Nursani (2014), } \\
\text { Prawira (2015), Zaini dan } \\
\text { Setiawan (2015) yaitu; } \\
\text { 1. kecurangan dilakukan } \\
\text { dalam keadaan terdesak } \\
\text { 2. tidak ada pihak yang } \\
\text { dirugikan } \\
\text { 3. Sanksi yang dinilai masih } \\
\text { rendah } \\
\text { 4. terbiasa melakukan } \\
\text { kecurangan } \\
\text { 5. Banyak orang lain yang } \\
\text { juga melakukan } \\
\text { kecurangan. }\end{array}$ & Skala Likert \\
\hline & $\begin{array}{l}\text { Kemampuan } \\
(\mathrm{X} 4)\end{array}$ & $\begin{array}{l}\text { Menurut Wolfe dan Hermanson } \\
\text { (2004) mendefinisikan } \\
\text { capability atau kemampuan } \\
\text { sebagai sifat-sifat pribadi dan } \\
\text { kemampuan yang memainkan } \\
\text { peran utama dalam } \\
\text { kecurangan akademik }\end{array}$ & $\begin{array}{l}\text { Menurut Wolfe dan } \\
\text { Hermanson(2004), indicator } \\
\text { dalam kemampuan seperti : } \\
\text { 1. pemahaman terhadap } \\
\text { pengendalian. } \\
\text { 2. Memiliki ego dan } \\
\text { keyakinan } \\
\text { 3. dapat mempengaruhi } \\
\text { orang lain } \\
\text { 4. dapat mengontrol stress } \\
\text { dengan baik. }\end{array}$ & Skala Likert \\
\hline & $\begin{array}{l}\text { Keserakahan } \\
\text { (X5) }\end{array}$ & $\begin{array}{l}\text { Mneurut Jack Bologne, } \\
\text { Greeds(Keserakahan) } \\
\text { berkaitan dengan adanya } \\
\text { perilaku serakah yang secara } \\
\text { potensial ada didalam diri } \\
\text { setiap orang. }\end{array}$ & $\begin{array}{l}\text { Adapun Variabel Greedy } \\
\text { menurut Zaini (2015) terdiri } \\
\text { atas beberapa indikator, } \\
\text { diantaranya: } \\
\text { 1. Sulit untuk merasa puas } \\
\text { 2. Terlihat unggul dari yang } \\
\text { lainnya } \\
\text { 3. Pelit berbagi ilmu untuk } \\
\text { mengurangi persaingan. }\end{array}$ & Likert \\
\hline $\begin{array}{c}\text { JAS-PT } \\
\text { JURNAL ANALISIS SISTEM PENDIIIKAN TINGGI } \\
\text { ISSN } 2580-5339 \\
\text { eISSN } 2620-5718 \\
\text { Volume } 5 \\
\text { Nomor } 1 \\
\text { JULI } 2021 \\
\text { Hal } 29-38\end{array}$ & $\begin{array}{l}\text { Kebutuhan } \\
\text { (X6) }\end{array}$ & $\begin{array}{l}\text { Menurut Teori Jack Bologne } \\
\text { kebutuhan (Needs) berkaitan } \\
\text { dengan faktor - faktor yang } \\
\text { dibutuhkan oleh individu - } \\
\text { individu untuk menunjang } \\
\text { hidupnya yang wajar. }\end{array}$ & $\begin{array}{l}\text { Variabel kebutuhan diukur } \\
\text { menggunakan indikator yang } \\
\text { dikembangkan oleh Indrawati } \\
\text { (2017) yaitu } \\
\text { 1. membutuhkan nilai yang } \\
\text { tinggi } \\
\text { 2. penguasaan materi kurang } \\
\text { 3. malas balajar dan } \\
\text { berusaha. }\end{array}$ & Likert \\
\hline DOSEN INDONESIA SEMESTA & $\begin{array}{l}\text { Pengungkapan } \\
(\mathrm{X} 7)\end{array}$ & $\begin{array}{l}\text { Menurut Teori dari Jack } \\
\text { Bologne pengungkapan }\end{array}$ & $\begin{array}{l}\text { Menurut Zaini (2015) dan } \\
\text { Dewani dan Chariri (2015) }\end{array}$ & Likert \\
\hline
\end{tabular}




\begin{tabular}{|c|c|c|c|}
\hline & $\begin{array}{l}\text { (exposures) berkaitan dengan } \\
\text { tindakan atau konsekuensi } \\
\text { yang dihadapi oleh pelaku } \\
\text { kecurangan apabila pelaku } \\
\text { diketemukan melakukan } \\
\text { kecurangan. }\end{array}$ & $\begin{array}{l}\text { variabel exposure } \\
\text { (pengungkapan) terdiri atas } \\
\text { beberapa indikator, } \\
\text { diantaranya: } \\
\text { 1. Peraturan yang monolistik } \\
\text { dan kurang tegas } \\
\text { 2. Kualitas peraturan kurang } \\
\text { memadai } \\
\text { 3. Kurangnya sosialisasi } \\
\text { peraturan } \\
\text { 4. Sanksi yang ringan, tidak } \\
\text { konsisten, dan tidak adil } \\
\text { 5. Kurangnya evaluasi } \\
\text { peraturan. }\end{array}$ & \\
\hline $\begin{array}{l}\text { Academic } \\
\text { Fraud }(Y)\end{array}$ & $\begin{array}{l}\text { Menurut Deighton (Irawati, } \\
\text { 2008), kecurangan akademik } \\
\text { adalah upaya yang dilakukan } \\
\text { seseorang untuk mendapatkan } \\
\text { keberhasilan dengan cara-cara } \\
\text { yang tidak jujur. }\end{array}$ & $\begin{array}{l}\text { Mennurut Wahyuningsih } \\
\text { (2018), Adiawati (2018), } \\
\text { Pamungkas (2018) variable } \\
\text { kecurangan akademik terdiri } \\
\text { atas: } \\
\text { 1. Plagiarisme } \\
\text { 2. Mencari alasan yang tidak } \\
\text { 3ebenarnya } \\
\text { 3. Mencontek dalam ujian } \\
\text { 4. Memalsukan bukti } \\
\text { kehadiran } \\
\text { 5. Bekerja sama dalam } \\
\text { kelompok }\end{array}$ & Likert \\
\hline
\end{tabular}

Peneliti memilih mahasiswa Jurusan Akuntansi IBI Kesatuan yang berstatus aktif pada semester genap tahun ajaran 2019/2020.Jumlah populasi pada penelitian ini adalah 1034 orang. Pemilihan sampel menggunakan metode cluster sampling, yaitu teknik pengambilan sampel dengan pemilihan mengacu pada kelompok bukan pada individu. Jumlah sampel dalam penelitian ini dihitung menggunakan rumus Slovin dengan menggunakan tingkat kesalahan sebesar $5 \%$ dan menghasilkan jumlah sampel sebanyak 288 mahasiswa.Namun pada pengumpulan kuesioner, penulis mendapatkan 306 respon dari kuesioner yang disebar. Metode pengumpulan data yang digunakan dalam penelitian ini adalah metode survei. Penelitian ini hanya melakukan pengumpulan data dengan kuesioner tertulis, dan tidak melakukan wawancara langsung terhadap responden. Pengujian hipotesis dilakukan dengan menggunakan metode analisisregresi berganda yang bertujuan untuk menguji apakah tekanan, kesempatan, rasionalisasi, kemampuan, keserakahan, kebutuhan dan pengungkapanberpengaruh terhadap academic fraud.

\section{HASIL DAN PEMBAHASAN}

\section{Data Responden}

Objek pada penelitian ini adalah mahasiswa aktif Prodi S1 Akuntansi Institut Bisnis dan Informatika Kesatuan Bogor Tahun Ajaran 2019/2020 Berdasarkan teknik sample cluster sampling. Data primer dalam penelitian ini yaitu kuesioner dalam bentuk Google Form yang dibagikan kepada mahasiswa S1 Akuntansi IBI Kesatuan melalui pesan pribadi maupun menyebarkan link kuesioner pada grup-grup Whatsapp kelas mahasiswa. Berdasarkan data yang penulis dapatkan dari $\mathrm{IBI}$ Kesatuan jumlah keseluruhan mahasiswa S1 Akuntansi berjumlah 1.034 orang. Dari total 1.034 hasil kuesioner yang terkumpul berjumlah 306 respon yang terdiri dari 197 perempuan, dan 109 laki-laki. 180 responden berasal dari kelas pagi, dan 126 responden berasal dari kelas karyawan. Dari 306 mahasiswi, presentasi tertinggi untuk semester yang sedang ditemput terdapat pada

\section{JAS-PT}

JURNAL ANALISIS SISTEM PENDIDIKAN TING ISSN $2580-5339$ elSSN $2620-5718$

Volume 5

Nomor 1

JULI 2021

Hal 29 - 38

DOSEN INDONESIA SEMESTA 
semester VII sebanyak $41,5 \%$ atau 127 responden, diikuti oleh semester IV $23,5 \%$ atau 72 responden, semester II 19,3\% atau 59 responden, dan semester VI 15,7\% atau 48 responden.

\section{Hasil Penelitian}

Tabel 2 Uji Statistik Deskriptif

\begin{tabular}{|c|c|c|c|c|c|c|c|c|c|}
\hline \multicolumn{10}{|c|}{ Statistics } \\
\hline & & Tekanan & $\begin{array}{c}\text { Kesempat } \\
\text { an }\end{array}$ & $\begin{array}{c}\text { Rasionali } \\
\text { sasi }\end{array}$ & $\begin{array}{c}\text { Kemampu } \\
\text { an }\end{array}$ & $\begin{array}{c}\text { Keseraka } \\
\text { han }\end{array}$ & $\begin{array}{c}\text { Kebutuha } \\
n\end{array}$ & $\begin{array}{c}\text { Pengungk } \\
\text { apan }\end{array}$ & $\begin{array}{c}\text { Kecurang } \\
\text { anAkadem } \\
\text { ik }\end{array}$ \\
\hline \multirow[t]{2}{*}{$\mathrm{N}$} & Valid & 306 & 306 & 306 & 306 & 306 & 306 & 306 & 306 \\
\hline & Missing & 0 & 0 & 0 & 0 & 0 & 0 & 0 & 0 \\
\hline \multicolumn{2}{|c|}{ Mean } & 13.25 & 12.79 & 14.80 & 10.28 & 7.32 & 8.45 & 13.26 & 16.03 \\
\hline \multicolumn{2}{|c|}{ Std. Error of Mean } & 0.277 & 0.195 & 0.263 & 0.206 & 0.116 & 0.185 & 0.163 & 0.268 \\
\hline \multicolumn{2}{|c|}{ Median } & 13.00 & 14.00 & 15.00 & 10.00 & 7.00 & 9.00 & 13.00 & 17.00 \\
\hline \multicolumn{2}{|c|}{ Std. Deviation } & \begin{tabular}{|c|}
4.847 \\
\end{tabular} & 3.411 & 4.604 & 3.599 & 2.030 & 3.241 & 2.850 & 4.687 \\
\hline \multicolumn{2}{|c|}{ Variance } & 23.494 & 11.633 & 21.194 & 12.950 & 4.120 & 10.504 & 8.122 & 21.967 \\
\hline \multicolumn{2}{|c|}{ Range } & 20 & 15 & 20 & 12 & 8 & 12 & 16 & 20 \\
\hline \multicolumn{2}{|c|}{ Minimum } & 5 & 4 & 5 & 4 & 4 & 3 & 4 & 5 \\
\hline \multicolumn{2}{|c|}{\begin{tabular}{|l|} 
Maximum \\
\end{tabular}} & 25 & 19 & 25 & 16 & 12 & 15 & 20 & 25 \\
\hline
\end{tabular}

Sumber : Data diolah SPSS 25

\section{Uji Kualitas Data}

Berdasarkan uji validitas, seluruh pernyataan dinyatakan valid. Berdasarkan uji reliabilitas, jawaban dari setiap responden dapat diandalkan atau reliabel. Hasil uji normalitas menggunakan p-plot menunjukkan titik menyebar di sekitar garis diagonal dan mengikuti arah garis diagonal, maka model regresi memenuhi asumsi normalitas. Hal ini berarti disimpulkan bahwa seluruh variabel dalam penelitian ini memiliki distribusi data yang normal.Berdasarkan grafik histogram uji normalitas dapat dikatakan normal karena membentuk lonceng. Hasil Uji Multikolinearitas menunjukan bahwa nilai tolerance dan nilai VIF pada variable tekanan, kesempatan, rasionalisasi, kemampuan, keserakahan, dan kebutuhan memilki nilai tolerance lebih besar dari $10(>0,10)$ dan nilai VIF lebih kecil dari $10(<10)$ sehingga dapat disimpulkan bahwa pada model regresi penelitian ini tidak terjadi multikolinearitas. Berdasarkan gambar scatterplot, tidak terdapat pola teratur dan terlihat titik-titik mennyebar diatas dan dibawah 0 (nol) pada sumbu Y, sehingga dapat disimpulkan bahwa model regresi pada penelitian ini tidak terjadi hetroskedastisitas.

\section{Analisis Regresi Linear Berganda}

Tabel 7 Hasil Analisi Regresi Linear Berganda

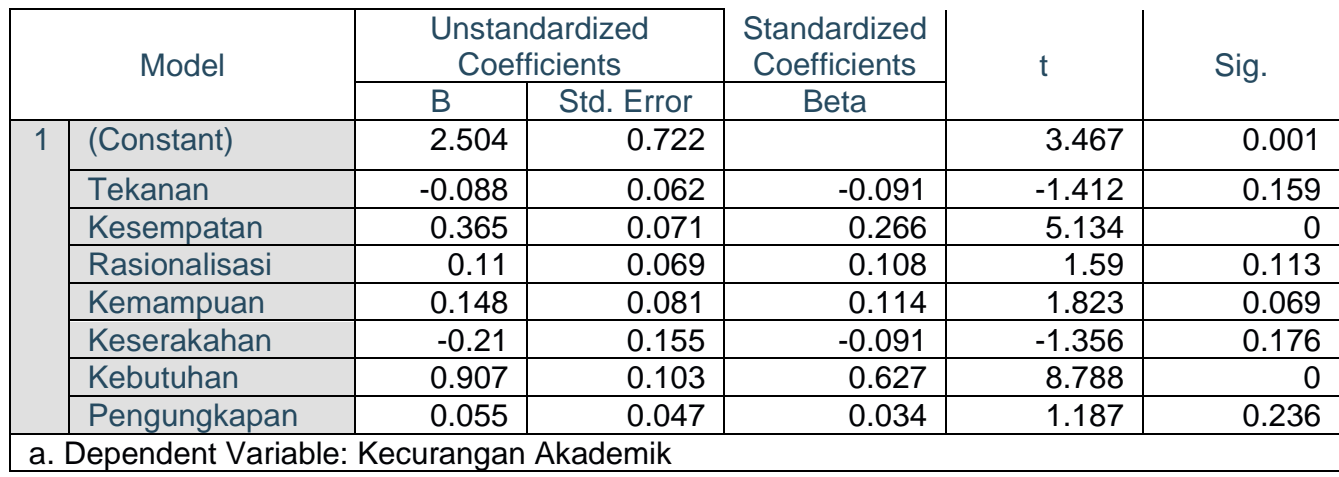

\section{Sumber: Output SPSS 25}

Berdasarkan hasil output SPSS dari uji regresi linear berganda, dapat dirumuskan persamaan regresi linear berganda sebagai berikut : 
$Y=2,504-0,088 \times 1+0,365 \times 2+0,11 \times 3+0,148 \times 4-0,21 \times 5+0,907 \times 6+0,055 \times 7$

Dimana : $Y=$ Kecurangan Akademik, $X 1=$ Tekanan, $X 2=$ Kesempatan, $X 3=$ Rasionalisasi, $\mathrm{X} 4=$ Kemampuan, $\mathrm{X} 5=$ Keserakahan, $\mathrm{X} 6=$ Kebutuhan, $\mathrm{X} 7=$ Pengungkapan

Uji Koefisien Determinasi (Adjusted R Square)

Tabel 8 Hasil Uji Koefisien Determinasi ( Adjusted R Square)

\begin{tabular}{|c|c|c|c|c|}
\hline \multicolumn{4}{|c|}{ Model Summary $^{\mathbf{b}}$} \\
\hline Model & R & R Square & Adjusted R Square & Std. Error of the Estimate \\
\hline 1 & $.890^{\mathrm{a}}$ & 0.792 & 0.787 & 2.164 \\
\hline
\end{tabular}

Sumber : Output SPSS 25

Berdasarkan hasil dari nilai $\mathrm{R}^{2}$ dan nilai adjusted $\mathrm{R}^{2}$, range variable independen dalam menjelaskan atau menerangkan variasi variable dependen sekitar $78,7 \%$ hingga $79,2 \%$. Dengan demikian, kemampuan variable dependen (tekanan, kesempatan, rasionalisasi, kemampaun, keserakahan, kebutuhan, dan pengungkapan) dalam penelitian ini untuk menerangkan atau menjelaskan variable dependen (kecurangan akademik) adalah sebesar $78,7 \%$ menurut hasil adjusted $\mathrm{R}^{2}$.

Uji Parameter Individual (Uji t)

$\mathrm{t}$ table $=\mathrm{t}(\mathrm{a} / 2: \mathrm{n}-\mathrm{k}-1)=\mathrm{t}(5 \% / 2: 306-7-1)=\mathrm{t}(0,025: 298)=1,967956=1,968$

Tabel 8 Hasil Uji t

\begin{tabular}{|l|r|r|}
\hline \multicolumn{1}{|c|}{ Variable } & \multicolumn{1}{c|}{ t hitung } & \multicolumn{1}{c|}{ Signifikasi } \\
\hline Tekanan & -1.412 & 0.159 \\
\hline Kesempatan & 5.134 & 0 \\
\hline Rasionalisasi & 1.59 & 0.113 \\
\hline Kemampuan & 1.823 & 0.069 \\
\hline Keserakahan & -1.356 & 0.176 \\
\hline Kebutuhan & 8.788 & 0 \\
\hline Pengungkapan & 1.187 & 0.236 \\
\hline
\end{tabular}

Sumber : Output SPSS 25

Berdasarkan data yang terdapat pada table 8 diperoleh hasil bahwa variable kesempatan dan kebutuhan memberikan pengaruh terhadap kecurangan akademik.

\section{Pembahasan}

\section{Pengaruh Tekanan Terhadap Kecurangan Akademik}

Pengujian dilakukan melalui signifikansi koefisien regresi variabel tekanan. Tekanan memiliki nilai koefisien negatif sebesar 0,088 dan sig. sebesar 0,159 lebih besar dari 0,05 $(0,129>0,05)$ sehingga hasil ini membuktikan bahwa factor tekanan tidak berpengaruh pada kecurangan akademik yang dilakukan oleh mahasiswa S1 Akuntansi Institut Bisnis dan Informatika Kesatuan. Hasil penelitian ini sejalan dengan penelitian Titi (2018), Nita(2018), Reza yang menyebutkan bahwa tekanan tidak berpengaruh pada kecurangan akademik. menurut penelitian Faisal (2018) banyak mahasiswa yang merasa tidak ditekan oleh orang tua nya, sehingga mahasiswa pun tidak merasa tertekan.

\section{Pengaruh Kesempatan Pada Kecurangan Akademik}

Hasil pengujian hipotesis kedua diketahui bahwa kesempatan berpengaruh pada kecurangan akademik mahasiswa S1 Akuntansi Institut Bisnis dan Informatika Kesatuan. Dilihat dengan kesempatan memilki nilai koefisien positif sebesar 0,365 dan Sig. sebesar 0 lebih kecil dari $0,05(0<0,05)$ hasil ini membuktikan bahwa kesempatan mempunyai

JAS-PT

JURNAL ANALISIS SISTEM PENDIDIKAN TINGGI ISSN $2580-5339$ eISSN $2620-5718$

Volume 5

Nomor 1 JULI 2021 Hal 29 - 38

DOSEN INDONESIA SEMESTA 
pengaruh positif terhadap perilaku kecurangan akademik. Hasil penelitian ini sejalan dengan hasil penelitian yang dilakukan Murdiansyah(2017), Pamungkas (2018), Wahyuningsih dengan menemukan hasil bahwa kesempatan berpengaruh terhadap academic fraud.

\section{Pengaruh Rasionalisasi Terhadap Kecurangan Akademik}

Hasil pengujian hipotesis ketiga diketahui bahwa rasionalisasi tidak berpengaruh pada kecurangan akademik mahasiswa S1 Akuntansi Institut Bisnis dan Informatika Kesatuan. Dilihat dengan rasionalisasi memilki nilai koefisien positif sebesar 0,11 dan Sig. sebesar 0,113 lebih besar dari $0,05(0,113>0,05)$ hasil ini membuktikan bahwa rasionalisasi tidak mempunyai pengaruh positif terhadap perilaku kecurangan akademik. Penelitian ini sejalan dengan penelitian Fasial(2018), Azis dan Novianti (2013). Dominan mahasiswa yang merasa bahwa kecurangan akademik adalah hal yang tidak pantas dilakukan oleh mahasiswa.

\section{Pengaruh Kemampuan Terhadap Kecurangan Akademik}

Hasil pengujian hipotesis keempat diketahui bahwa kemampuan tidak berpengaruh pada kecurangan akademik mahasiswa S1 Akuntansi Institut Bisnis dan Informatika Kesatuan. Dilihat dengan kemampuan memiliki nilai koefisien positif sebesar 0,148 dan Sig. sebesar 0,069 lebih besar dari $0,05(0,069>0,05)$ hasil ini membuktikan bahwa kemampuan tidak mempunyai pengaruh positif terhadap perilaku kecurangan akademik. Hal tersebut sejalan dengan penelitian Zaini, Carolina \& Setiawan (2016), Faisal (2018), Titi (2018). Pada penelitian ini mahasiswa tidak memiliki elemen pendukung dalam kemampuan seperti yang dijelaskan Wolfe dan Hermanson (2004).

\section{Pengaruh Keserakahan Terhadap Kecurangan Akademik}

Hasil pengujian hipotesis kelima diketahui bahwa keserakahan tidak berpengaruh pada kecurangan akademik mahasiswa S1 Akuntansi Institut Bisnis dan Informatika Kesatuan. Dilihat dengan keserakahan memilki nilai koefisien negatif sebesar 0,21 dan Sig. sebesar 0,176 lebih besar dari $0,05(0,176>0,05)$ hasil ini membuktikan bahwa keserakahan tidak mempunyai pengaruh positif terhadap perilaku kecurangan akademik. Penelitian ini sejalan dengan peneltian Nita (2018) dan Kurniawan (2014), Luluk (2018). Hal ini terjadi mungkin disebabkan karena mahasiswa IBI Kesatuan merasa mudah puas dengan nilai mata kuliah ataupun IPK (Indeks Prestasi Kumulatif) yang didapat.

\section{Pengaruh Kebutuhan Terhadap Kecurangan Akademik}

Hasil pengujian hipotesis keenam diketahui bahwa kebutuhan berpengaruh pada kecurangan akademik mahasiswa S1 Akuntansi Institut Bisnis dan Informatika Kesatuan. Dilihat dengan kebutuhan memilki nilai koefisien positif sebesar 0,907 dan Sig. sebesar 0 lebih kecil dari $0,05(0<0,05)$ hasil ini membuktikan bahwa kebutuhan mempunyai pengaruh positif terhadap perilaku kecurangan akademik. Akibatnya semakin timbul rasa butuh dari dalam diri mahasiswa yang dipengaruhi baik dari dalam dirinya sendiri maupun lingkungannya maka akan semakin besar juga tindak kecurangan akademik yang akan dilakukan oleh mahasiswa. Penelitian ini sejalan dengan penelitian Ismatullah dan Eriswanto (2016), Nita (2018), Indrawati dkk (2017).

\section{Pengaruh Pengungkapan Terhadap Kecurangan Akademik}

Hasil pengujian hipotesis ketujuh diketahui bahwa pengungkapan tidak berpengaruh pada kecurangan akademik mahasiswa S1 Akuntansi Institut Bisnis dan Informatika Kesatuan. Dilihat dengan pengungkapanmemilki nilai koefisien positif sebesar 0,055 dan Sig. sebesar 0,236 lebih besar dari $0,05(0,236>0,05)$ hasil ini membuktikan bahwa pengungkapan tidak mempunyai pengaruh positif terhadap perilaku kecurangan akademik. Didukung dengan penelitian Kurniawan (2014), Ismet (2016). Hal ini terjadi diduga karena mahasiswa S1 Akuntansi IBI Kesatuan merasa bahwa peraturan, sanksi dan sosialisasi yang akan diterima oleh mahasiswa sudah dinilai cukup memadai. 


\section{SIMPULAN DAN SARAN}

Hasil penelitian menunjukan bahwa indicator kesempatan dan kebutuhan merupakan faktor yang menyebabkan mahasiswa S1 Akuntansi Institut Bisnis dan Informatika Kesatuan melakukan tindak kecurangan akademik. Faktor tekanan, rasionalisasi, kemampuan, keserakahan, kebutuhan dan pengungkapan tidak menyebabkan mahasiswa S1 Akuntansi Institut Bisnis dan Informatika Kesatuan untuk melakukan tindak kecurangan akademik. Mahasiswa IBI Kesatuan masih dapat mengelola tekanan yang datang sehingga tidak menjadikan tekanan sebagai salah satu factor utama mahasiswa melakukan kecurangan akademik. kecurangan akademik dilakukan apabila melihat kesempatan yang tersedia. Mahasiswa merasa bahwa usaha pengungkapan yang dilakukan oleh Institut Bisnis dan Informatika kesatuan sudah cukup baik dan memadai untuk memberikan efek jera pada pihak yang melakukan tindak kecurangan akademik sehingga sebenarnya mahasiswa S1 Akuntansi Institut Bisnis dan Informatika sudah memahami konsekuensi yang akan didapatkan apabila tetap melakukan tindak kecurangan akademik. Namun factor kesempatan dan kebutuhan yang menjadi factor utama mahasiswa S1 Akuntansi Institut Bisnis dan Informatika Kesatuan membuat mahasiswa mengabaikan peraturan yang berlaku mengenai konsekuensi yang akan diterima apabila mahasiswa ketahuan melakukan tindak kecurangan akademik.

\section{DAFTAR PUSTAKA}

Adiawati, Titi. 2018. Perilaku Kecurangan Akademik Mahasiswa Akuntansi : Dimensi Fraud Diamond (Studi Kasus Pada Mahasiswa Prodi Akuntansi Universitas Islam Indonesia). Universitas Islam Indonesia. Jogjakarta.

Amyar, F., Hidayah, N. N., Lowe, A., \& Woods, M. (2019). Investigating the backstage of audit engagements: the paradox of team diversity. Accounting, Auditing \& Accountability Journal.

Arens, A. A., Elder, R. J., dan Beasley, M. S. 2010.Auditing dan Jasa Assurance. Alih Bahasa: Herman Wibowo dan Tim Perti. Penerbit Erlangga. Jakarta.

Artani, K. T. B dan Wetra, I.W. 2017.Pengaruh Academic Self Efficacy dan Fraud Diamond Terhadap Perilaku Kecurangan Akademik Mahasiswa Akuntansi Di Bali. Jurnal Riset Akuntansi, Vol 7(2) : 125-132

Budiman, N. A. 2018. Perilaku Kecurangan Akademik Mahasiswa: Dimensi Fraud Diamond Dan Gone Theory. Akuntabilitas Jurnal Ilmu Akuntansi Vol 11(1): 75-90.

Diany, Y. A. 2014. Determinan Kecurangan Laporan Keuangan: Pengujian Teori Fraud Triangle. Laporan Keuangan Yang Dikeluarkan Oleh Otoritas jaasa Keuangan.

Hasanah, N dan Diana, N. 2014. Analisis Pengaruh Fraud Diamond Dan GoneTheory Terhadap Academic Fraud: Studi Kasus Terhadap Mahasiswa Program Studi Akuntansi Perguruan Tinggi Negeri Dan Perguruan Tinggi Swasta Di Malang.

Isgiyata, J., Indayani, dan Budiyani, Eko. 2018. Studi Tentang Teori Gone dan Pengaruhnya Terhadap Fraud Dengan Idealisme Pimpinan Sebagai Variabel Moderasi: Studi Pada pengadaan Barang/ Jasa di Pemerintahan. Jurnal Dinamika Akuntansi dan Bisnis Vol 5(1): 31-42.

Ismatullah dan eriswanto.2016. Analisa Pengaruh Teori Gone Fraud Terhadap Academic Fraud Di Universitas Muhammadiyah Sukabumi.Riset Akuntansi dan Keuangan Indonesia 1(2).

Lewellyn, P. G dan Rodriguez, L. C. 2015. Does Academic Dishonesty Relate to Fraud Theory? A Comparative Analysyis. American International Journal Of Contemporary Research, Vol 5(3): 1-6.

JAS-PT

JURNAL ANALISIS SISTEM PENDIDIKAN TINGGI ISSN $2580-5339$ elSSN $2620-5718$

Volume 5

Nomor 1

JULI 2021

Hal $29-38$

DOSEN INDONESIA SEMESTA 
Little, Jack dan Handel, Stephanie. 2016. Student Cheating And The FraudTriangle. Bussiness Education Forum: 37-44.

Mulyana, M. (2012). Consumer Behaviour: Sukses Dengan Memahami Konsumen.

Murdiansyah, I., Sudarma, M. S, dan Nurkholis. 2017. Pengaruh Dimensi Fraud Diamond Terhadap perilaku kecurangan Akademik: Studi Empiris Pada Mahasiswa Magister Akuntansi Universitas Brawijaya. Jurnal Akuntansi Aktual, Vol 4(2): 121133.

Purnamasari, D. 2013. Faktor-Faktor Yang Mempengaruhi Kecurangan Akademik Pada Mahasiswa.Educational Psychology Journal Vol 2(1): 13-15.

Putriasih, K., Herawati, N. N., Wahyuni, M. A. 2016. Analisis Fraud Diamond Dalam Mendeteksi Financial Statement Fraud: Studi Empiris Pada Perusahaan Manufaktur Yang Terdaftar Di Bursa Efek Indonesia tahun 2013-2015.

Ristianingsih, Ika. Telaah Konsep Fraud Diamond Theory Dalam Mendeteksi Perilaku Fraud Di perguruan Tinggi. Materi prosiding Seminar Nasional dan Call For Paper Ekonomi dan Bisnis, Jember, 27-28 Oktober 2017.

Romney, M. B., Steinbart, P.J. 2015. Sistem Informasi Akuntansi. Alih Bahasa: Kikin Sakinah Nur Safira, Novita Puspasari. Salemba Empat. Jakarta.

Rujoiu, Octavian Dan Rujoiu, Valentina. Academic Dishonesty, Anoverview. Proceeding Of The 8th International Management Conference. Bucharest, Romania, 6-7 November 2014.

Setiani, Luluk. 2018. Determinan Academic fraud Dalam Dimensi Determinan Fraud Diamond dan GONE Theory (Studi Empiris Mahasiswa Akuntansi Angkatan 2014 Fakultas Ekonomi dan Bisnis Universitas Muhammadiyah Surakarta). Univesitas Muhamadiyah Surakarta.

Wahyuningsih, Intan. 2018. Analisi Pengaruh Gone Theory, Integritas Dan Religiusitas Terhadap Academic Fraud: Studi Kasus Pada Mahasiswa Akuntansi Universitas Negeri Di Kota Malang.

Zaini, M. A. Carolina, dan A. R. Setiawan. (2015). Analisis Pengaruh Fraud Diamond dan Gone Theory terhadap Academic Fraud (Studi Kasus Mahasiswa Akuntansi SeMadura). Simposium Nasional Akuntansi 1

Zamzam, Irfan.,Suriana AR Mahdi, dan Resmiyati Ansar. (2017). "Pengaruh Diamond Fraud dan Tingkat Religiuitas Terhadap Kecurangan Akademik (Studi Pada Mahasiswa S-1 Di Lingkungan Perguruan Tinggi Se Kota Ternate)". Jurnal IImiah Akuntansi Peradaban 1. Vol: III No: 2

JAS-PT

JURNAL ANALISIS SISTEM PENDIDIKAN TINGG

ISSN $2580-5339$

eISSN $2620-5718$

Volume 5

Nomor 1

JULI 2021

Hal $29-38$

DOSEN INDONESIA SEMESTA 